ISSN = 1980-993X-doi:10.4136/1980-993X
www.agro.unitau.br/ambi-agua
E-mail: ambi-agua@agro.unitau.br
Tel.: (12) 3625-4116

\title{
Evaporative cooling: water for thermal comfort
}

(doi:10.4136/ambi-agua.52)

\author{
José Rui Camargo \\ Mechanical Engineering Department, UNITAU, University of Taubaté \\ E-mail: rui@unitau.br
}

\begin{abstract}
Evaporative cooling is an environmentally friendly air conditioning system that operates using induced processes of heat and mass transfer, where water and air are the working fluids. It consists, specifically, in water evaporation, induced by the passage of an air flow, thus decreasing the air temperature. This paper presents three methods that can be used as reference for efficient use of evaporative cooling systems, applying it to several Brazilian cities, characterized by different climates. Initially it presents the basic operation principles of direct and indirect evaporative cooling and defines the effectiveness of the systems. Afterwards, it presents three methods that allows to determinate where the systems are more efficient. It concludes that evaporative cooling systems have a very large potential to propitiate thermal comfort and can still be used as an alternative to conventional systems in regions where the design wet bulb temperature is under $24^{\circ} \mathrm{C}$.
\end{abstract}

Keywords: evaporative cooling; air conditioning; thermal comfort.

\section{Resfriamento evaporativo: água para conforto térmico}

\section{RESUMO}

Resfriamento evaporativo é um sistema de condicionamento de ar ambientalmente amigável, que opera por meio de processos induzidos de transferência de calor e massa, nos quais a água e o ar são os fluidos de trabalho. Consiste na evaporação de água, induzida pela passagem de uma corrente de ar, o que provoca uma redução na temperatura do ar. Este trabalho apresenta três métodos que podem ser utilizados como referência para a aplicação eficiente de sistemas de resfriamento evaporativo, aplicando-os a algumas cidades brasileiras, caracterizadas por condições climáticas diversas. Apresenta-se, inicialmente o princípio de operação dos sistemas de resfriamento evaporativo direto e indireto e define-se a efetividade dos sistemas. Após, são apresentados os três métodos, concluindo-se que os sistemas de resfriamento evaporativo tem grande potencial para oferecer conforto térmico, podendo ser utilizado como uma alternativa aos sistemas de condicionamento de ar convencionais em regiões onde a temperatura de bulbo úmido de projeto é menor que $24^{\circ} \mathrm{C}$.

Palavras-chave: resfriamento evaporativo; condicionamento de ar; conforto térmico. 


\section{INTRODUCTION}

An evaporative cooling system operates using induced processes of heat and mass transfer, where water and air are the working fluids. It consists, specifically, in water evaporation, induced by the passage of an air flow, thus decreasing the air temperature. When water evaporates into the air to be cooled, simultaneously humidifying it, that is called direct evaporative cooling (DEC) and the thermal process is the adiabatic saturation. The main characteristic of this process is the fact that it is more efficient when the temperatures are higher, that means, when more cooling is necessary for thermal comfort. It has the additional attractiveness of low energy consumption and easy maintenance. Due to use total airflow renewal, it eliminates the recirculation flow and proliferation of fungi and bacteria, a constant problem in conventional air conditioning systems. Due to its characteristics the evaporative cooling system is more efficient in places where the climate is hot and dry but it can also be used under other climatic conditions.

\section{RECENT DEVELOPMENTS}

Several authors dedicated their researches to the development of direct and indirect evaporative cooling systems. Watt (1963) developed the first serious analyses of direct and indirect evaporative systems; Leung (1995) presents an experimental research of the forced convection between an air flow and an inner surface of a horizontal isosceles triangular duct; Halaz (1998) presented a general dimensionless mathematical model to describe all evaporative cooling devices used today; Camargo, Cardoso and Travelho (2000) developed a research where a thermal balance study for direct and indirect cooling systems was developed; Camargo and Ebinuma (2002) presented the principles of operation for direct and indirect evaporative cooling systems and the mathematical development of the equations of thermal exchanges, allowing for the determination of heat transfer convection coefficients for primary and secondary air flow; Dai and Sumathy (2002) investigated a cross-flow direct evaporative cooler, in which the wet honeycomb paper constitutes the packing material and the results indicate that there exists an optimum length of the air channel and the performance can be improved by optimizing some operation parameters; Liao and Chiu (2002) developed a compact wind tunnel to simulate evaporative cooling pad-fan systems and tested two alternative materials; Al-Sulaiman (2002) evaluated the performance of three natural fibers (palm fiber, jute and luffa) to be used as wetted pads in evaporative cooling; Camargo, Ebinuma and Silveira (2003) presents a thermoeconomic analysis method based on the first and second law of thermodynamics and applied to an evaporative cooling system coupled to an adsorption dehumidifier; Hasan and Sirén (2003) investigated the performance of two evaporatively heat exchangers operating under similar conditions of air flow and inlet water temperatures; Camargo, Ebinuma and Cardoso (2003) presents the basic principles of the evaporative cooling processes for human thermal comfort and presents the mathematical development of the thermal exchanges equations, allowing the determination of the effectiveness of saturation. 


\section{EVAPORATIVE COOLING SYSTEMS}

The principle underlying direct evaporative cooling is the conversion of sensible heat to latent heat. Non-saturated air is cooled by heat and mass transfer increases by forcing the movement of air through an enlarged liquid water surface area for evaporation by utilizing blowers or fans. Some of the sensible heat of the air is transferred to the water and becomes latent heat by evaporating some of the water. The latent heat follows the water vapor and diffuses into the air.

Figure 1 shows a schematic direct evaporative cooling system, where water is running in a loop and the makeup water entering the sump to replace evaporated water must be at the same adiabatic saturation temperature of the incoming air. In a DEC, the heat and mass transferred between air and water decreases the air dry bulb temperature (DBT) and increases its humidity, keeping the enthalpy constant (adiabatic cooling) in an ideal process. The minimum temperature that can be reached is the thermodynamic wet bulb temperature (TWBT) of the incoming air. The effectiveness of this system is defined as the rate between the real decrease of the DBT and the maximum theoretical decrease that the DBT could have if the cooling were $100 \%$ efficient and the outlet air were saturated. Practically, wet porous materials or pads provide a large water surface in which the air moisture contact is achieved and the pad is wetted by dripping water onto the upper edge of vertically mounted pads.

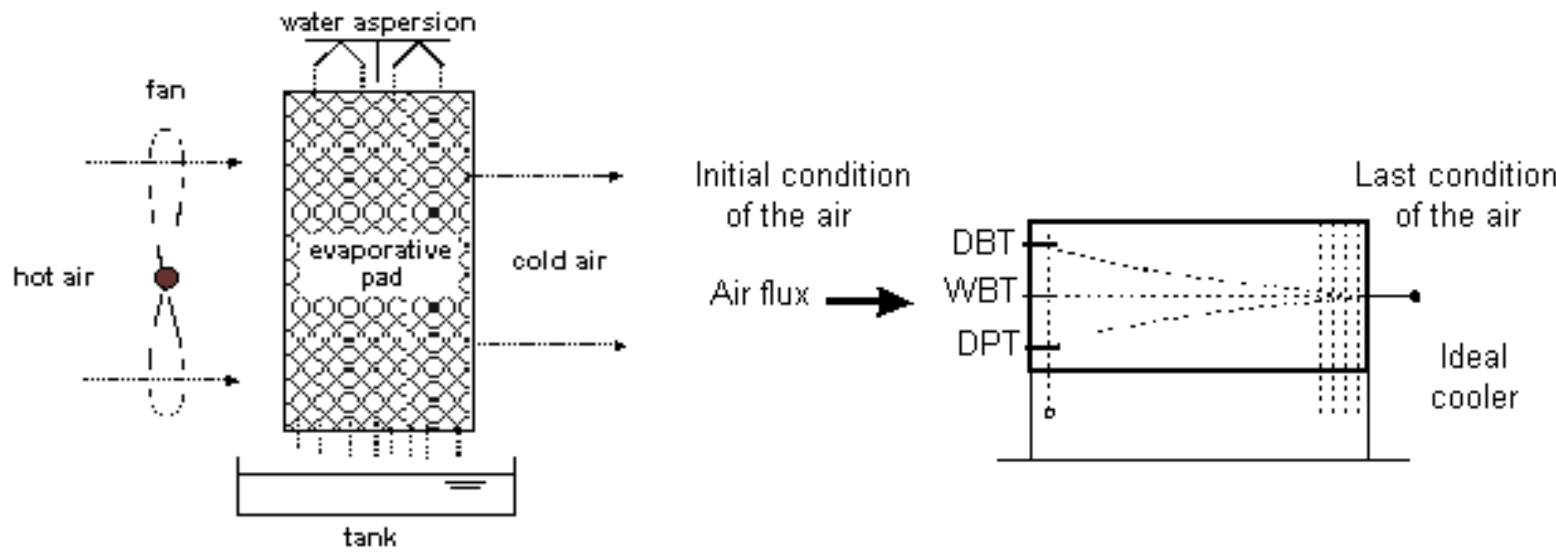

Figure 1. Direct evaporative cooling (DEC).

Another system uses indirect cooling equipment, where air, relatively dry, is separated from the wet airside, where liquid have been evaporated. In the indirect evaporative cooling system (IEC), the process air (primary air) transfers heat to a secondary airflow or to a liquid that has been cooled by evaporation.

Both dry side and air enthalpy on this side are decreased, in contrast to the temperature adiabatic decrease of a direct evaporative cooling. Figure 2 shows two kinds of indirect evaporative cooling system: plate type (Fig. 2a) and tube type (Fig. 2b).

The effectiveness of an evaporative cooling is defined as the rate between the real decrease of dry bulb temperature and the maximum theoretical decrease that dry bulb temperature could have if the cooling were $100 \%$ efficient and the outlet air were saturated. In this case the outlet dry bulb temperature would be equal to the inlet wet bulb temperature (Trane, 1978). 


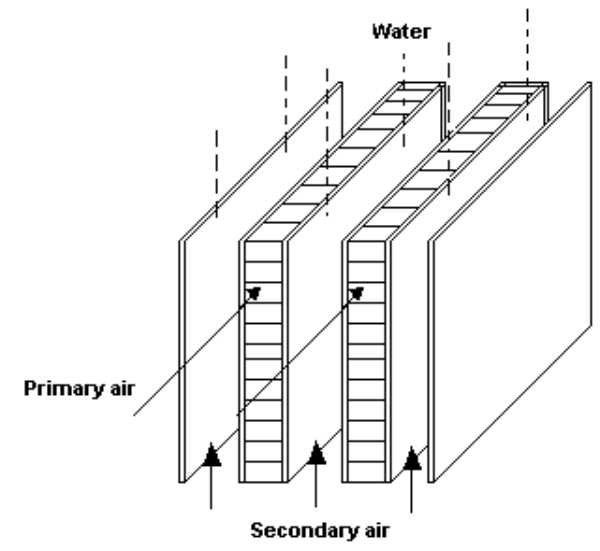

(a)

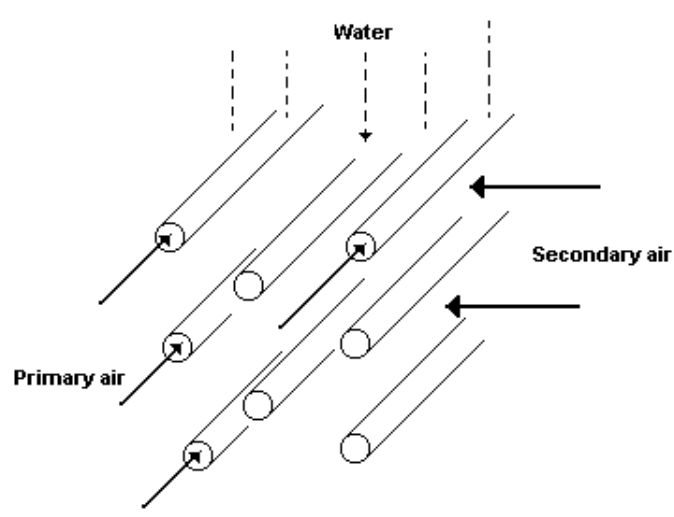

(b)

Figure 2. Indirect evaporative cooling: (a) plate, (b) tube.

For an ideal evaporative cooler, it means, $100 \%$ efficient, the dry bulb temperature and dew point should be equal to the wet bulb temperature.

The psychometric chart in Fig. 3 illustrates what happens when the air runs through an evaporative unit. Assuming the condition that the inlet dry bulb temperature is $35^{\circ} \mathrm{C}$ and the wet bulb temperature is $25^{\circ} \mathrm{C}$ (point 1 ), the initial difference is $10^{\circ} \mathrm{C}$. The process $1-2$ represents an indirect evaporative unit and the process 1-3 represents a direct evaporative unit. If the efficiency of the direct unit is $90 \%$ (Munters, 1999), the depression will be $9^{\circ} \mathrm{C}$ and the dry bulb temperature of the air leaving this unit will be $35-0.9 \times 10=26^{\circ} \mathrm{C}$ (point 3 ). Taking a 70\% efficiency for the indirect unit (Munters, 1999), the dry bulb temperature of the air leaving this unit will be $28^{\circ} \mathrm{C}$ (point 2).

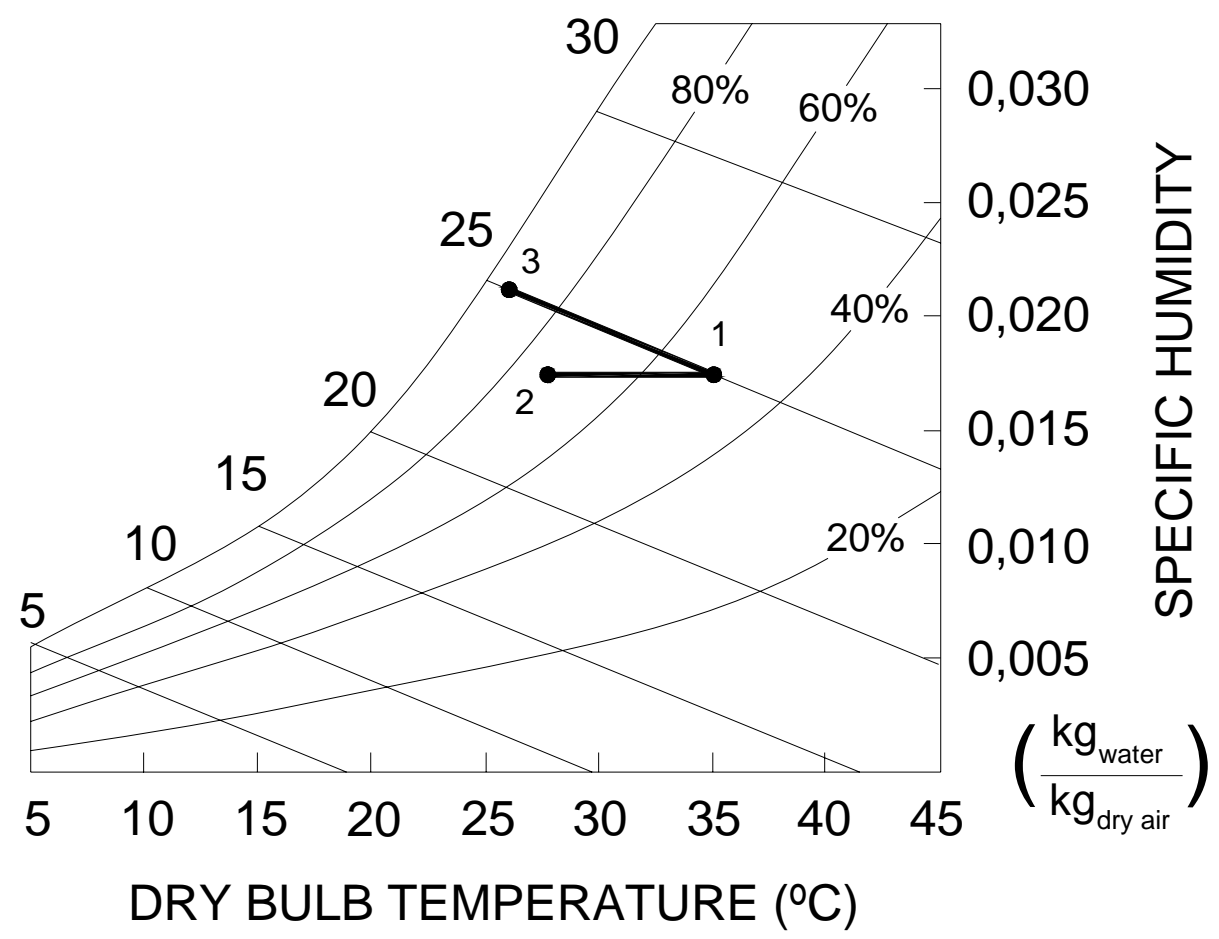

Figure 3. Psychometric chart showing the condition: (1) outside air, (2) air leaving the indirect unit and (3) air leaving the direct unit. 


\section{PERFORMANCE OF INDIRECT AND DIRECT SYSTEM FOR SOME PLACES}

Direct and indirect evaporative coolers can be coupled in order to reach some thermal comfort conditions. A typical arrangement couples, in series, first an indirect evaporative cooler and, after, a direct one. The performance expected for the direct and indirect evaporative cooling systems is show in Table 1. It was determined for outside conditions with design dry bulb temperature and wet bulb temperature coincidence of $1 \%$ for the cities selected. The effectiveness of direct system was assumed with $70 \%$ and in the indirect system with $90 \%$ (Munters, 1999).

Table 1. Outlet stages temperatures.

\begin{tabular}{l|c|c|c}
\hline \multicolumn{1}{c|}{ City } & $\begin{array}{c}\text { DBT (Design)/ } \\
\text { WBT coincident (1\%) }\end{array}$ & $\begin{array}{c}\text { DBT outlet } \\
\text { indirect stage }\left({ }^{\mathbf{0}} \mathbf{C}\right)\end{array}$ & $\begin{array}{c}\text { DBT outlet } \\
\text { direct stage }\left({ }^{\mathbf{0}} \mathbf{C}\right)\end{array}$ \\
\hline Belém & $32,3 / 27$ & 28,6 & 26,4 \\
Belo Horizonte & $30 / 24,4$ & 26,1 & 23,7 \\
Brasília & $30 / 22$ & 24,4 & 22,7 \\
Curitiba & $30 / 23$ & 25,1 & 22,1 \\
Florianópolis & $32 / 27,1$ & 28,6 & 26,6 \\
Fortaleza & $31,4 / 26$ & 27,6 & 25,4 \\
Maceió & $32 / 25,7$ & 27,6 & 24,6 \\
Natal & $31,5 / 25,7$ & 27,5 & 25,0 \\
Porto Alegre & $35 / 26,3$ & 28,9 & 25,4 \\
Recife & $31,6 / 25,8$ & 27,6 & 25,1 \\
Rio de Janeiro & $35,3 / 27,3$ & 29,7 & 26,5 \\
Salvador & $31,2 / 26,1$ & 27,6 & 25,5 \\
São Luis & $32,5 / 26,5$ & 28,3 & 25,8 \\
São Paulo & $30,6 / 23$ & 25,3 & 22,0 \\
Vitória & $33,5 / 27,4$ & 29,3 & 26,7 \\
\hline \multicolumn{3}{|c}{}
\end{tabular}

\section{METHODS TO EVALUATE EVAPORATIVE COOLING SYSTEMS}

This section presents three methods that may be used to verify the viability of using evaporative cooling equipment of air conditioning for human thermal comfort (Camargo, 2000) and their application to several cities.

\subsection{Method 1: feasibility index}

A fast method to evaluate approximately the potential of the evaporative cooling is based on the Feasibility Index (FI), defined by:

$\mathrm{FI}=\mathrm{WBT}-\Delta \mathrm{T}$

Where $* \mathrm{~T}=(\mathrm{DBT}-\mathrm{WBU})$ is the wet bulb depression. DBT and WBT are, respectively the dry bulb temperature and the wet bulb temperature of the outside air. This index decreases as the difference between dry bulb and wet bulb temperature increases, i.e. as air relative 
humidity decreases. It shows that, the smaller FI is, more efficient the evaporative cooling will be. Thus, this number indicates the evaporative cooling potential to give thermal comfort.

Watt (1963) recommend that indices that are under or equal to 10 indicate a comfort cooling, indices between 11 and 16 indicate lenitive cooling (relief) and indices above 16 classify the place as not recommended for use evaporative cooling systems.

From these limits it is possible to conclude that, to reach a comfort recommended performance index, a wet bulb depression from, at least, $12^{\circ} \mathrm{C}$, is needed. It corresponds, e.g. to a DBT of $34^{\circ} \mathrm{C}$ with $\mathrm{WBT}$ of $22^{\circ} \mathrm{C}$, characterizing a region with relative humidity of approximately $35 \%$.

\subsection{Method 2: cooling process vectors}

Another method to determine evaporative cooling potential is through a psychometric chart giving comfort areas and vectors representing the cooling process. Local climatic condition must be plotted in this chart giving the vector application point. If, through evaporative cooling vector representation is possible to reach the comfort zone, then evaporative systems are possible to be used in that region.

Figure 4 shows vectors of three different cooling processes:

$\mathrm{AB}$ - direct evaporative cooling

$\mathrm{AD}$ - indirect first stage (AC) and direct second stage (CD)

EF - conventional air conditioning

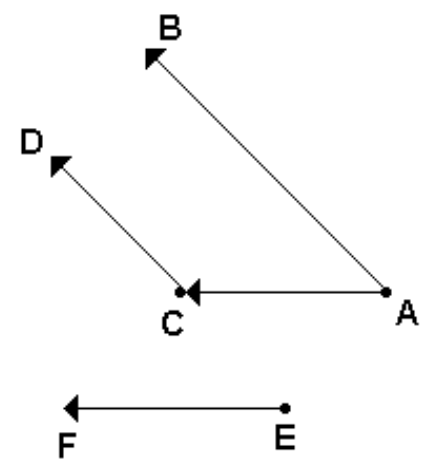

Figure 4. Cooling process vectors.

This method determines, in the psychometric chart, a zone, from where it is possible to reach the comfort zone by means of direct or indirect cooling. To determine this zone limits, values of the specific humidity were fixed and its corresponding dry bulb temperature (DBTC) on the limit line of the comfort zone were obtained, that is,

$$
\mathrm{DBT}_{\mathrm{C}}=\mathrm{DBT}_{\mathrm{L}}-\varepsilon_{\mathrm{i}}\left(\mathrm{DBT}_{\mathrm{L}}-\mathrm{WBT}\right)
$$

Where DBTC is the dry bulb temperature in the limit line on the right and DBTL is the dry bulb temperature in the limit line of the ASHRAE comfort zone. With the help of a software developed by the authors, the values of its corresponding wet bulb temperature WBTW and, finally, the DBTL temperature of the above equation where obtained.

If the point is under the representative line of an IEC with $*_{\mathrm{i}}=60 \%$ or $70 \%$ it is possible to use this system for comfort cooling. Figure 5 shows the result. 


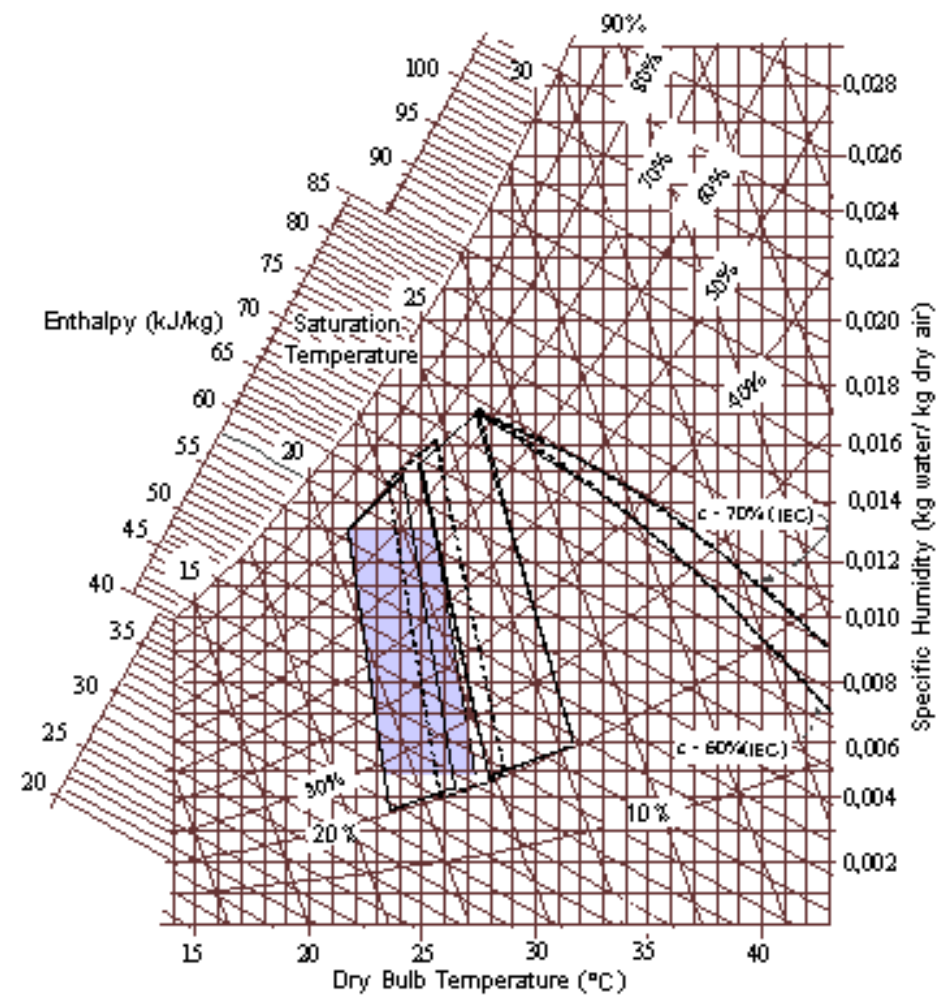

Figure 5. Delimitation of the area where it is possible to reach the evaporative cooling comfort area.

\subsection{Method 3: nomograph and template}

This method is an adaptation of what was proposed by Watt (1963) and by Watt and Brown (1997).

If both final indoor or process condition are known for each region, the effective temperature chart allows the determination of the maximum permissible local outdoor wet bulb temperature and the minimum average outdoor wet bulb depression required for such performance. The first one becomes the maximum permissible design wet bulb temperature for the location and the latter is converted into the required minimum design wet bulb depression.

Figure 6 is an adapted thermometric chart that shows the interaction, during summer, of the dry bulb temperature, wet bulb temperature and air speed in the representation of the effective temperature. ASHRAE comfort zone for $41^{\circ}$ North Latitude (the first comfort chart was made in Pittsburgh, in this latitude) has been superimposed upon it, its upper limit on $26.1^{\circ} \mathrm{C}$ temperature effective.

To determine the outdoor climatic condition necessary to achieve the comfort cooling, as defined above, a calculator template, showed in its inferior side, is used and it is useful to fix the comfort cooling limits (superior template) and to the relief (inferior template).

In order to use the template, first it is necessary to copy it into a transparent paper. Then put it over the chart with the "indoor conditions" line crossing the intersection of the maximum permissible air speed with the regional comfort zone maximum permissible effective temperature. The template lower right intersection indicates maximum outdoor wet bulb temperature able to give comfort, under the given conditions. The template maximum difference between dry bulb temperature and wet bulb temperature indicates the minimum average outdoor wet bulb depression required. 


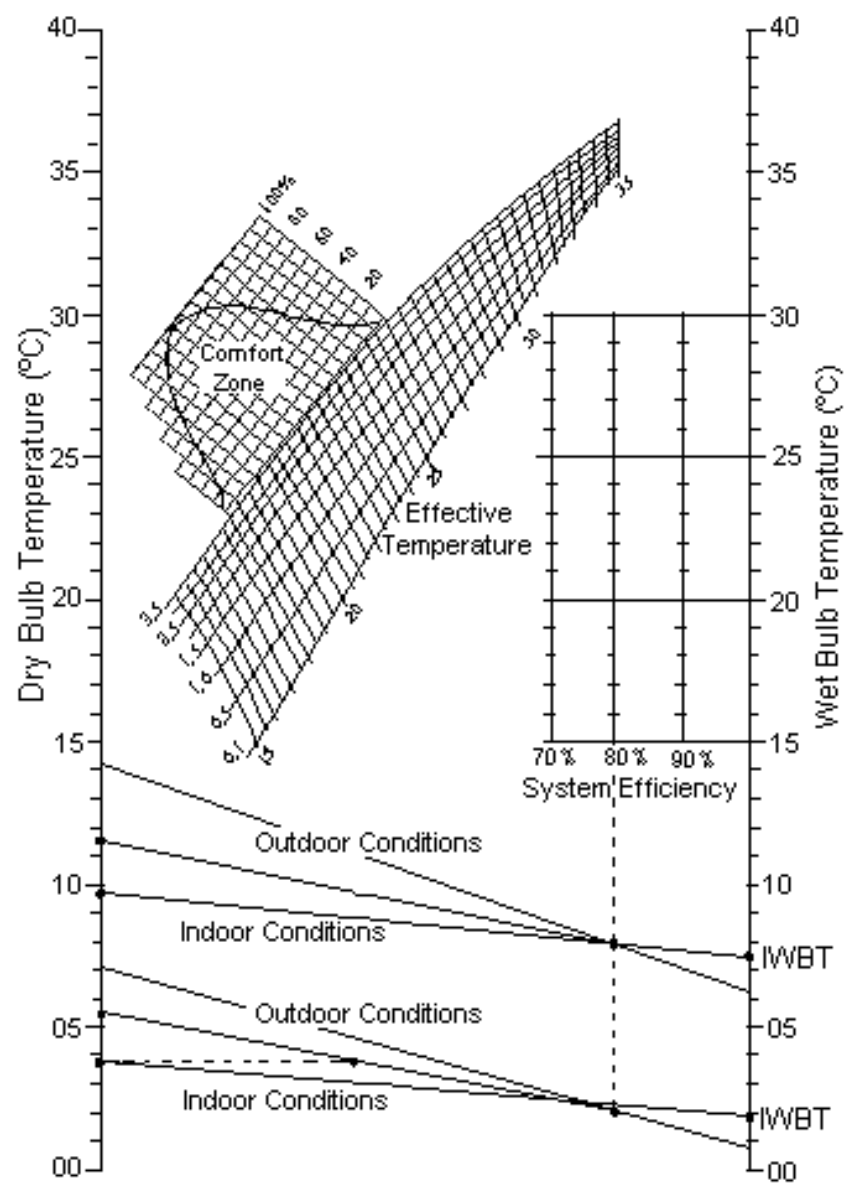

Figure 6. Nomograph and template.

Watt (1963) says that comfort cooling through DEC in the $41^{\circ}$ north latitude (Pittsburgh) must give a $26.1^{\circ} \mathrm{C}$ effective temperature, requiring design WBT not above $24.8^{\circ} \mathrm{C}$.

\section{ECONOMY}

There are, now a days in operation, more than 20 millions of residential evaporative cooling in all world, saving approximately 60 millions of petroleum's drum and avoiding the emission of 27 billions of CO2 pounds yearly. In the USA, only the fair of residential evaporative cooling moves US\$ 180 millions in the year, with more than 4 millions of units installed. The cost per unit of equipment is between US\$ 35 for simple direct system and US\$ 2000 for completely systems with ducts, and the average cost between US\$ 300 and US\$ 700 . The direct settling reduce the operation costs between $25 \%$ and $40 \%$ when is compared with costs of mechanicals refrigeration only (ASHRAE, 1995), to produce the same cooling effect. A direct/indirect system can be saving between $40 \%$ and $50 \%$ of energy in moderately wet areas.

\section{RESULTS AND DISCUSSION}

Using the method called "feasibility index (FI)", whose values give the possibility of obtaining cooling for comfort or relief, it is possible to check that performance index values 
under or equal to 10 are obtained, for example, to Cordoba and Tucaman, in Argentina, and Santiago, in Chile. In Brazil it is possible to find indices between 11 and 16 for Petrolina (PE), Uberlândia (MG), Campinas (SP), Pirassununga (SP), Brasilia (DF), Campo Grande (MT), Londrina (PR), Caxias do Sul (RS) and Santa Maria (RS), among others.

Through "vectors cooling process" method it is possible to verify that a basic requirement to fit onto a region where it is possible to reach the comfort zone is the wet bulb temperature being below $24^{\circ} \mathrm{C}$. In regions where climatic conditions do not allow reaching the comfort zone only through evaporative cooling, it is possible to use a pre-dehumidification process of the air by adsorption, direct / indirect associated systems or to use the mechanical cooling as a support system. Some cities whose climates conditions allow arrive the ASHARE comfort zone only with evaporative cooling are: Belo Horizonte (MG), Brasília (DF), Campinas (SP), Caxias do Sul (RS), Curitiba (PR), Londrina (PR), São Paulo (SP) and Uberlândia (MG), among others. For places with climates conditions that no allow arrive the comfort are only through the evaporative cooling can be used in process of predehumidification the air by adsorption or mechanicals refrigeration support.

The method called "nomograph and template" allows to determinate the maximum design WBT and, through it, it is possible to obtain the results described below.

The comfort zone increases the effective temperature curve by $5^{\circ} \mathrm{C}$ for each $5^{\circ}$ reduction in latitude. Evaporative cooling placed in northern Argentina, Uruguay and Rio Grande do Sul must obtain maximum $26.8^{\circ} \mathrm{C}$ ET (effective temperature), requiring $24.4^{\circ} \mathrm{C}$ design WBT or lesser, for air speed of $0.1 \mathrm{~m} / \mathrm{s}$. At the same way, with the same air speed, regions in northern Rio Grande do Sul, Santa Catarina and in southern Paraná must have $27.3^{\circ} \mathrm{C}$ ET or less, where $24.9^{\circ} \mathrm{C}$ is the maximum permissible design WBT. In northern Paraná, São Paulo, Rio de Janeiro, Mato Grosso do Sul and in southern Minas Gerais the comfort cooling needs to obtain $27.8^{\circ} \mathrm{C}$ ET or less, requiring the maximum design WBT of $25.5^{\circ} \mathrm{C}$. Northern Minas Gerais and southern Mato Grosso and Goiás require maximum design WBT of $26^{\circ} \mathrm{C}$. Bahia, southern Tocantins, northern Mato Grosso, Rondonia and Acre require maximum design WBT of $26.6^{\circ} \mathrm{C}$. Southern Maranhão, northern Tocantins, southern Pará and southern Amazonas request maximum design WBT of $27.3^{\circ} \mathrm{C}$. Finally, the northern Maranhão, northern Pará, northern Ceará, northern Amazonas, Amapá and Roraima require maximum design WBT of $27.9^{\circ} \mathrm{C}$. The values presented above are related to the maximum required design WBT, that is, the temperature that takes to the upper limit of the comfort zone presented in the nomograph of Fig.7. For WBT values providing comfort to $100 \%$ of the occupants, the temperatures presented above must be reduced in approximately $4.5^{\circ} \mathrm{C}$.

\section{CONCLUSIONS}

This paper presents a methodology and a systematic study related to evaporative cooling systems applied to tropical and equatorial regions and the methods presented here are useful to evaluate the technical viability of evaporative cooling systems for human thermal comfort. It allows to the correct determination of where and how evaporative cooling systems can be efficiently used.

Evaporative cooling systems, although not widely used in Brazil, have a very large potential to produce thermal comfort and can be an alternative to the conventional systems in regions where the wet bulb temperature is relatively low. Moreover, it may also be used with conventional systems where only the evaporative system cannot supply all of the needs for comfort. Some possible alternatives are the multistage systems and the adsorption prehumidifying systems. 
Regions with design wet bulb temperature lower than $24^{\circ} \mathrm{C}$ are places where evaporative cooling air conditioning systems may be used with great efficiency.

The most important data for an engineer or designer, however, when considering evaporative system applications, is updated climatic registers for each specific region in order to find out what can be done with regard to thermal comfort.

The methods presented in this paper, although illustrated for evaporative cooling, may also be used for other air conditioning systems.

\section{ACKNOWLEDGEMENTS}

The author wish to acknowledge the technical support provided by CNPq (Conselho Nacional do Desenvolvimento Científico e Tecnológico).

\section{REFERENCES}

AL-SULAIMAN, F. Evaluation of the performance of local fibers in evaporative cooling. Energy Conversion \& Management, Oxford, v. 43, p.2267-73, 2002.

AMERICAN SOCIETY OF HEATING, REFRIGERATING AND AIR CONDITIONING ENGINEERS. ASHRAE handbook applications. Si Ed. Atlanta: ASHRAE, 1995. Cap. 47.

CAMARGO, J. R. Análise de métodos para avaliar a viabilidade técnica de sistemas de resfriamento evaporativo aplicados ao condicionamento de ar para conforto. 2000, 106f. Dissertação (Mestrado em Engenharia Mecânica) - Universidade de Taubaté, Taubaté, 2000.

CAMARGO, J. R.; CARDOSO, S.; TRAVELHO, J. S. Condicionamento de ar por resfriamento evaporativo. In: CONGRESO CHILENO DE ENGENHARIA MECÂNICA, 9., CONGRESO NACIONAL COCIM-CONAE 2000, 4., Valparaiso, 2000. Proceedings... Valparaiso: [S.n]., 2000.

CAMARGO, J. R.; EBINUMA, C. D. A mathematical model for direct and indirect evaporative cooling air conditioning systems. In: BRAZILIAN CONGRESS OF THERMAL ENGINEERING AND SCIENCES, ENCIT, 9., João Pessoa, 2002. Proceedings... João Pessoa: UFPB, 2002. p. CIT02-0855.

CAMARGO, J. R.; EBINUMA, C. D.; CARDOSO, S. A mathematical model for direct evaporative cooling air conditioning system. Engenharia Térmica, Curitiba, n. 04, p. 30-34, 2003.

CAMARGO, J. R.; EBINUMA, C. D.; SILVEIRA, J. L. Thermoeconomic analysis of an evaporative desiccant air conditioning system. Applied Thermal Engineering, n. 23, p.1537-2549, 2003.

DAI, Y. J.; SUMATHY, K. Theoretical study on a cross-flow direct evaporative cooler using honeycomb paper as packing material. Applied Thermal Engineering, v. 22, p.14171430, 2002.

HALAZ, B. A. A General mathematical model of evaporative cooling devices. Rev. Gén. Therm. Elsevier, Paris, v. 37, p.245-255, 1998. 
HASAN, A.; SIRÉN, K. Performance investigation of plain and finned tube evaporatively cooled heat exchangers. Applied Thermal Engineering, v. 23, p.325-340, 2003.

LEUNG, C. W. Forced convection inside horizontal isosceles triangular ducts. In: IMECHE Conference Transactions. London: Mechanical Engineering Publications, 1995. p.117-121.

LIAO, C.; CHIU, K. Wind tunnel modeling the system performance of alternative evaporative cooling pads in Taiwan region. Building and Environment, v. 37, p.177-187, 2002.

MUNTERS BRASIL. Sistema de ventilação com resfriamento através do processo natural de evaporação da água. Curitiba: Munters, 1999. 1 Apostila mimeografada.

TRANE COMPANY. Trane air conditioning manual. La Crosse: The Trane Company, 1978. 456p.

WATT, J. R. Evaporative air conditioning. New York: The Industrial Press, 1963. 300p.

WATT, J. R.; BROWN, W. K. Evaporative air conditioning handbook. 3. ed. Lilburn: The Fairmont Press, 1997. 507 p. 